\title{
Melatonin Receptor Type 1B
}

National Cancer Institute

\section{Source}

National Cancer Institute. Melatonin Receptor Type 1B. NCI Thesaurus. Code C79764.

Melatonin receptor type 1B (362 aa, $\sim 40 \mathrm{kDa}$ ) is encoded by the human MTNR1B gene.

This protein plays a role in both ligand recognition and signal transduction. 